\title{
INFRA-BIM FOR BUSINESS PROCESSES' MANAGEMENT IN ROAD CONSTRUCTION AND OPERATION
}

\author{
Victoria Shamraeva*, Evgeniy Savinov \\ Financial University under the Government of the Russian Federation \\ Leningradsky avenue, 49, Moscow, Russia \\ ${ }^{*}$ Corresponding author: VVShamraeva@fa.ru
}

\begin{abstract}
Introduction: The article addresses the business processes of the construction and operation of linear road sections. In the course of the study, we analyzed the geographic information system (GIS) of Avtodor company (developer: Indor-Soft, Tomsk) and its use in the operation and maintenance of transport infrastructure facilities at such road sections. In particular, we studied the construction of the Far West Krasnodar Bypass (FWKB), which is part of the North-South transport corridor, and its implementation by means of InfraBIM modeling. Purpose of the study: We aimed to describe the structured GIS database of Avtodor company by connecting various InfraBIM tools for the purposes of data generation and road model update. Methods: Analyzing the GIS of Avtodor company when using an InfraBIM model of road infrastructure, we studied the following: use of GIS features at the facility; asynchronous editing and selection of data without access to the Internet; database update. Results: InfraBIM models of linear road sections, developed in the implementation of such projects as the FWKB, make it possible to optimize time and save money when planning and introducing measures during the operation of transport infrastructure facilities.
\end{abstract}

\section{Keywords}

BIM modeling, road information model, geographic information system, transport infrastructure, digital transformation of roads, InfraBIM for road construction and maintenance.

\section{Introduction}

Building Information Modeling (BIM) development and implementation imply the creation of a Common Data Environment (CDE) to obtain the necessary information about transport infrastructure facilities and urban planning (Boykov et al., 2017). The issues of standardization and creation of a database of information models in road construction and urban planning are quite crucial. It is required to develop a regulatory framework that would contribute to the successful implementation of BIM in Russia. The use of BIM models at various stages of the life cycle of capital construction facilities is regulated by Decree of the Government of the Russian Federation No. 1431, dated September 15, 2020, "On approval of the rules for forming and maintaining information models of capital construction facilities, the composition of information, documents and materials included in information models of capital construction facilities and submitted in the form of electronic documents, and the requirements for the formats of these electronic documents, as well as amendments to Paragraph 6 of the Regulations on engineering surveys for the preparation of design documentation, construction, and reconstruction of capital construction facilities", signed by Chairman of the Government of the Russian Federation Mikhail Mishustin (https://ipbd.ru/doc/0001202009220002/).
A number of road organizations are working on the use of BIM tools: road information models (Shamraeva, 2020b), databases, and automated systems for processing road data banks, including on the Web. In contrast to capital construction facilities and their information models (Hardin and McCool, 2015), in the case of linear transport infrastructure facilities, design and construction are carried out for individual (separate) sections. Such sections may have different implementation periods (e.g., construction, operation, and repair may be carried out on the same road simultaneously), and the project is usually performed by several contractors. Thus, BIM implementation in transport infrastructure differs from that regarding industrial and civil construction facilities: during design, it is required to use InfraBIM for motor roads, transferring data to the GIS during operation so as to obtain a complete BIM model of the road (Shamraeva, 2020a). According to the action plan, dated December 18, 2017, in the direction "Formation of research competencies and technological groundwork" within the program "Digital Economy of the Russian Federation" (action item 03.00.000.001.18.11 - development of software for the instrumentation control of the diagnostic state of roads, intended for the collection, accumulation, storage, consolidation, analysis and interactive visual representation of data on the state of roads, received from various testing and measuring 
equipment, management authorities, and population), it is necessary to consider the requirements of applicable statutes and regulations in terms of import substitution and gradual transition to the preferential use of domestic software (https://www.sbras.ru/files/news/ docs/tex_zadely_d_e_plan.pdf). The tools and software used for the analysis of the business processes at Avtodor company make it possible to optimize time and save money when planning and introducing measures during the operation of facilities.

\section{Subject, tasks, and methods}

Let us consider the stages of the road facility life cycle in terms of BIM modeling of linear road sections (Fig. 1).

Fig. 1 shows a simplified representation of this cycle. A more detailed scheme was presented by Skvortsov and Sarychev (2015).

\section{Information modeling at the stage of surveys} and design

The article addresses the business processes of the construction and operation of roads and transport infrastructure at Avtodor company. Specialists of Avtodor company together with contractors and construction supervisors implement InfraBIM to optimize surveys, avoid collisions and errors during geodetic works, control the volume of construction and installation works, and visualize the plan-fact analysis.

At this stage, the following documentation and data on works are introduced to the database:

- detailed design documentation;

- documentation for land cadastral works;

- as-built documentation, including logs, work sheets, drawings, diagrams, and calculations;

- estimate documentation for new types of work;

- main and auxiliary works in accordance with the design, detailed design or other technical documentation for the facility;

- materials, structures, equipment, etc. used during works at the facility.

In particular, we studied the construction of the Far West Krasnodar Bypass (FWKB), which is part of the North-South transport corridor. Its construction is performed by Avtodor company using a number of the following information systems in its work: GIS IndorRoad, WebGIS "Navigation System for Design and Actual Data Management", and S-Info. To ensure communication between information systems, a Common Data Environment is created.

The GIS of Avtodor company ensures accounting and certification of roads, as well as road operation management and life cycle support. On the website https://avtodor-eng.ru/services/arenda-spetstekhniki/ geoinformatsionnye-sistemy/, the main GIS tasks and corresponding functions are listed.

Transport infrastructure is intended for safe and comfortable movement of its users. One of the main conditions for its formation is its digitalization (Gibadullin et al., 2020). It is obvious that, with a Common Data Environment, BIM designers will develop design documentation much faster and at a lower cost. To manage transport infrastructure facilities, the following GIS are used: ArcGIS (ESRI company), IndorRoad (IndorSoft company), MapInfo (MapInfo company), free QGIS, DorGIS (Intelnova company), and so on (Shamraeva et al., 2018). Avtodor company develops its own approach to the use of BIM and GIS technologies in construction supervision. We analyzed its business processes with account for the use of GIS in the operation and maintenance of FWKB transport infrastructure facilities. In particular, we studied the following:

- the possibility to use GIS features at the facility;

- asynchronous editing and selection of data without access to the Internet;

- a corresponding set of data on the facilities;

- database update.

To justify the investment in the project, a summary model of the FWKB was developed (Project model_2108018_dop_attributes.nwd) in Autodesk Navisworks in the NWD file format, which is a data exchange format for summary models. This format is static, which means that the data contained in the file cannot be changed or used to create $2 \mathrm{D}$ drawings.

During FWKB summary model development, a set of requirements was formulated for each layer of the Construction Work section (coordinate system, accuracy, attributes, stationing, phasing, etc.), including the following layers:

- road center line, junctions, exits and adjoining roads; stationing;

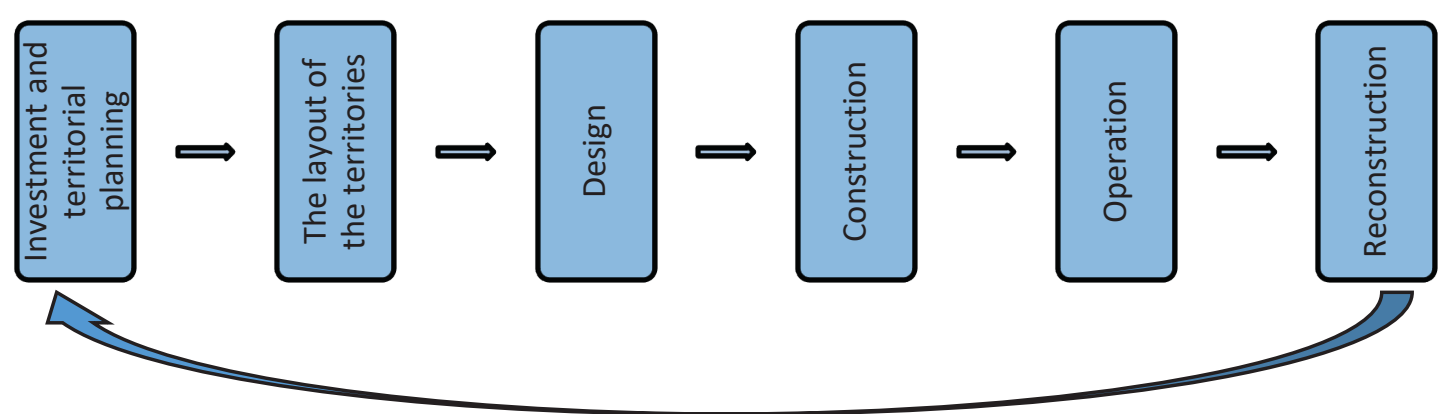

Figure 1. Stages of the road facility life cycle 
- road bed boundaries;

- artificial structures: buildings, bridges, pipes, wells;

- protected zones: burial ground for cattle; nature reserve; mineral resources; etc.;

- utilities;

- areas of planned works;

- forest compartments, land plots, boundaries of districts;

- aerial photography.

Thus, the Customer handed over to the construction contractor the information model of the facility as part of the design documentation in the Common Data Environment, meeting the following requirements:

- The structure of surfaces and corresponding data organization shall ensure the creation of files to be uploaded to the system for road construction machinery automated control.

- Data organization in information models shall ensure the creation of data sheets, work sheets, and tables to provide the supply of materials and machinery for road construction.

- The structure of an information model shall ensure the connection between the linear scheduling diagrams and elements of the model, thus visualizing the sequence of road construction works.

The construction contractor shall develop an asbuilt model of completed construction, equivalent to the design model in terms of the structure of data, and representing the constructed facility's actual state.

Let us take a closer look at the Avtodor GIS features and their use at the facility under consideration. The geometric parameters of the information model elements are completely correct, and the level of detail is very high. The portal with information on facilities has an adaptive web interface optimized for display on a computer or a mobile device. The elements in the GIS database are requested by selecting a multi-level menu or by selecting objects in the map and entering the section of the corresponding facility. Let us list the main disadvantages:

1. Since it is difficult to select elements in the map using the cursor when navigating on mobile devices, an interface is required that would be more adapted to mobile devices and configured to meet the needs of specialists working at the facility.

2. It is impossible to enter information online (perhaps, this is due to the access rights granted for audit). It is obvious that if data are to be uploaded at the site, it is important to ensure that the person generating these data can enter them right away (and not later in the office).

3. $3 G / 4 G$ network coverage is not available in some areas at the site where specialists work. The availability of only the web version limits the use of the system. Therefore, it is required to consider a solution for extracting data for a specific work area. Besides, if data are to be entered at the site where no Internet access is available, an asynchronous mode of database operation will be required.

4. The Attribute Tables contain a fairly large set of data (more than 250 unique properties of database objects, in addition to geometric characteristics and symbols). However, there is a lack of data required for the GIS use to obtain information about current and future construction projects or serving as a basis for the operation and maintenance of infrastructure facilities. Firstly, there is no information about the validity of data: the source of data, the corresponding accuracy, etc. For instance, it is impossible to know whether the position of a pipe crossing a road was determined during design or geodetic surveys. Secondly, the number of documents on artificial structures is quite limited, and often only photos are available.

5. Finally, in many cases, no data on technical surveys of structures are available. If such data are available, they are contained in a PDF file corresponding to a specific structure rather than presented as object metadata.

Among the portal advantages, the flexible web interface can be mentioned, which includes the following:

1. Viewing of detailed information on the facility and linked documents; going to the map.

2. Map of motor roads with utilities (up to a scale of 1:500) with the interactive change of scale and area for viewing, the formation of a set of layers, the inclusion of auxiliary layers: aerial survey, satellite images, the cadastral map of the Federal Service for State Registration, Cadaster and Cartography (Rosreestr).

3. Distance and area measurement.

4. Analytical functions. Calculation of the quantity, total length and area (if applicable) for the selected types of road facilities (with breakdown by districts, regions, roads).

5. Viewing of panoramic video shots. Point selection, view direction in the map, period selection (year and season), the possibility of moving along the road center line.

Let us describe the possibility of using GIS features at the facility. The portal with information on facilities has an adaptive web interface optimized for display on a computer or a mobile device. The elements in the GIS database are requested by selecting a multi-level menu or by selecting objects in the map and entering the section of the corresponding facility. However, it is difficult to select elements in the map using the cursor when navigating on mobile 
devices and impossible to select the illumination pole in the map: the corresponding menu section is not displayed in the screen area, and the menu is not drop-down (Fig. 2).

If data are to be uploaded at the site, it is important to ensure that the person generating these data can enter them right away (and not later in the office). An interface is required that would be more adapted to mobile devices and configured to meet the needs of specialists working at the facility. Besides, it is impossible to enter information online (perhaps, this is due to the access rights granted for audit).

The content of the GIS of Avtodor company can be judged by the number of objects in the database and the quality of data entry (seemingly indivisible polygons). The GIS contains a large number of photos of infrastructure facilities with a 360-degree view (Fig. 3). The navigation interface in photos with a 360 -degree view is very fast, which makes it possible to significantly improve performance efficiency.

To ensure more efficient management of road facilities, a Common Data Environment (CDE) is required that would timely provide reliable information (Znobishchev and Shamraeva, 2019b). The basic principles of CDE operation include the following:

- verified and reliable information on the facility, obtained from external sources, used by referencing, combining, or direct exchange;

- clearly defined information requirements provided by stakeholders of the project or asset (with a high level of detail) and by the customer (with a higher level of detail);

- the CDE is provided for the management and storage of publicly available information in accordance with the security policy and division of access rights between those generating, using, and supporting this information;

- processes related to information security provision, in place throughout the entire service life of the road (road section), required to resolve problems related to unauthorized access, information loss, theft or damage, and, as far as possible, return to outdated information.

At the stage of construction, the CDE maintains a continuous transition of the Design Model to the Detailed Design and As-Built Models. Upon completion of construction, the information containers required for road management shall be transferred from the information model of the project to the information model of the asset (operation). The remaining information containers related to the project (including those at an archived state) shall be read-only in the case of disputes and for experience gaining.

Thus, it is impossible to use the database to determine the number of objects that need to be supported and maintained in X years. It is recommended to introduce changes in data management to account for support and maintenance of structures.

The database shall be updated with the use of a special program. IndorRoad has the iFC data exchange format implemented for integrating data from BIM models. This function will be necessary in the future for infrastructure construction and reconstruction projects. To update plans and network diagrams, the ETL (Extract, Transform, Load) pro-
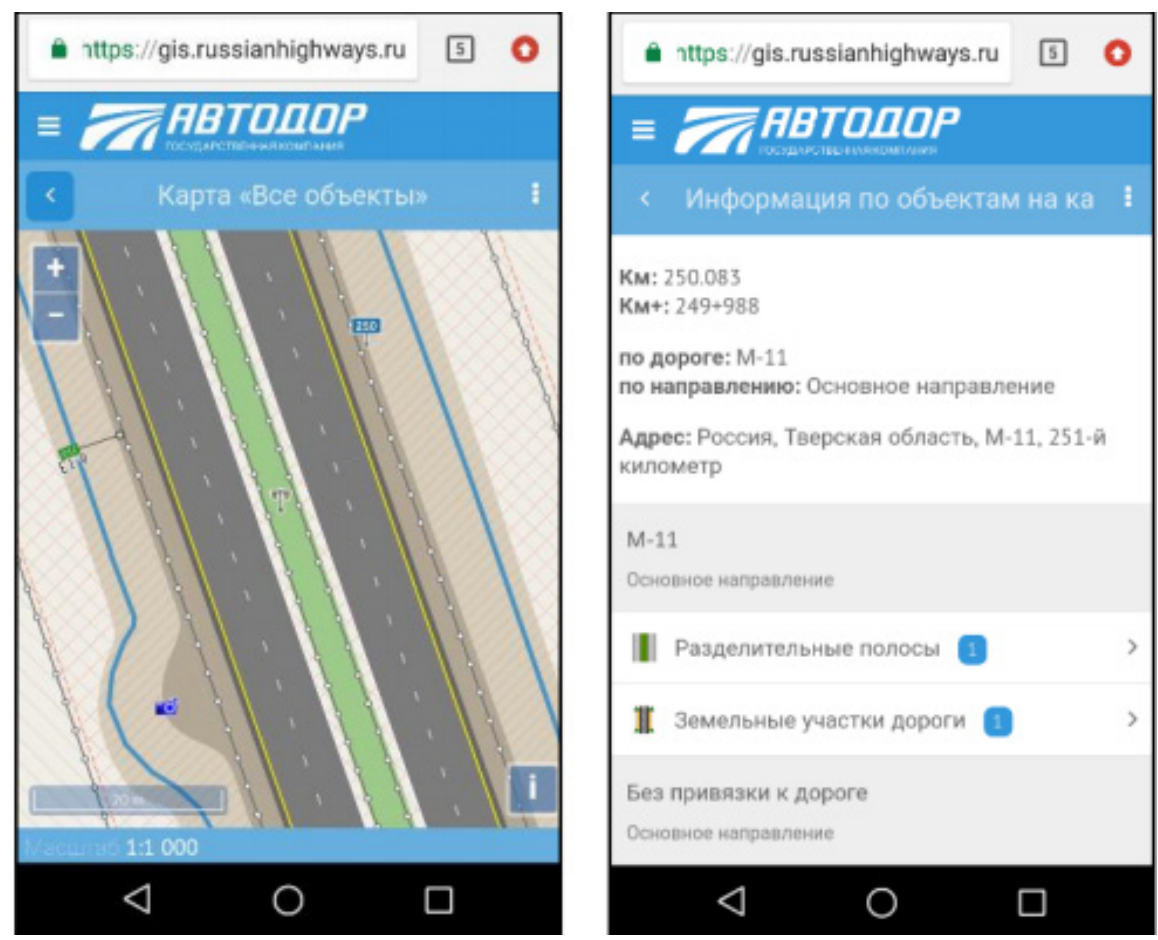

Figure 2. Screenshot from a mobile device 
cedure can be used when connecting directly to the CDE without using IndorRoad. This issue should be addressed in order to limit human intervention in data entry.

\section{Method development}

At the current stage of road digitalization in Russia, the practical use of BIM modeling for road infrastructure facilities plays a significant part. Tools and software developed and used for road diagnostics serve as the information basis that could be integrated into intelligent transport systems (Kazeev, 2020). Let us describe the methods of developing an information model for linear road sections during surveys and design as well as the interaction in the CDE at the stage of project implementation.

Development of a road information model during surveys and design

Currently, there are no powerful domestic CAD systems that would make it possible to automate design and surveys and serve as the source of the fundamental data set for building full-fledged BIM models of roads. While in the field of industrial and civil construction, the element base is significantly developed, the field of road construction has a small number of such developments. In many cases, designers have to analyze and redraw the same standard structures without resorting to the capabilities of computer-aided design.

Another BIM issue is the consideration of requirements for the level of detail of the information model at the stage of design documentation development. On the one hand, the level of detail shall not be too high, i.e., the model shall not have elements that will not be used during construction and operation. On the other hand, the level of detail shall be sufficient for construction and installation, construction supervision, and acceptance of deliverables as well as subsequent facility operation.
When planning a project using BIM tools and 3D coordination with the subsequent transfer of the necessary information, the basic levels of detail of information model elements (or the so-called Levels of Development (LODs)) are determined (The American Institute of Architects, 2013). Each LOD (BSI, 2013) contains information about the execution of project tasks that correspond to a particular level of detail. Each project may have five LODs: LOD 100, LOD 200, LOD 300, LOD 400, and LOD 500 (Barannik, 2017). In some cases, LOD 350 (intermediate lev$\mathrm{el}$ ) is added to these LODs (Abbasnejad and Moud, 2013). LOD 350 provides contractors with more complete information (Eastman et al., 2011) and is required during bidding organization. Analysis of the business processes related to the construction and operation of linear road sections shows that for the project team to develop clear justified requirements for information models as well as minimum requirements for the information richness of model elements before the commencement of the project, LOD 500 (AIA E203-2013) is optimal (Abbasnejad and Moud, 2013). This LOD reflects the actual dimensions, bindings, etc. to the fullest extent. These data are then transferred to the operation service (Fig. 4).

As a rule, BIM models are developed for the design stage. Therefore, they shall not be used in road operation or maintenance since the model intended for use by the operating organization shall reflect the actual constructed facility. In the current state, BIM models can be used to get an idea of construction and installation works as well as structures under construction. However, they contain a large amount of 3D data and very little attribute data, which makes it impossible to use the project BIM model in its current state for operation and maintenance tasks. The BIM model shall be filled with information throughout the entire life cycle of the project, and the need for its

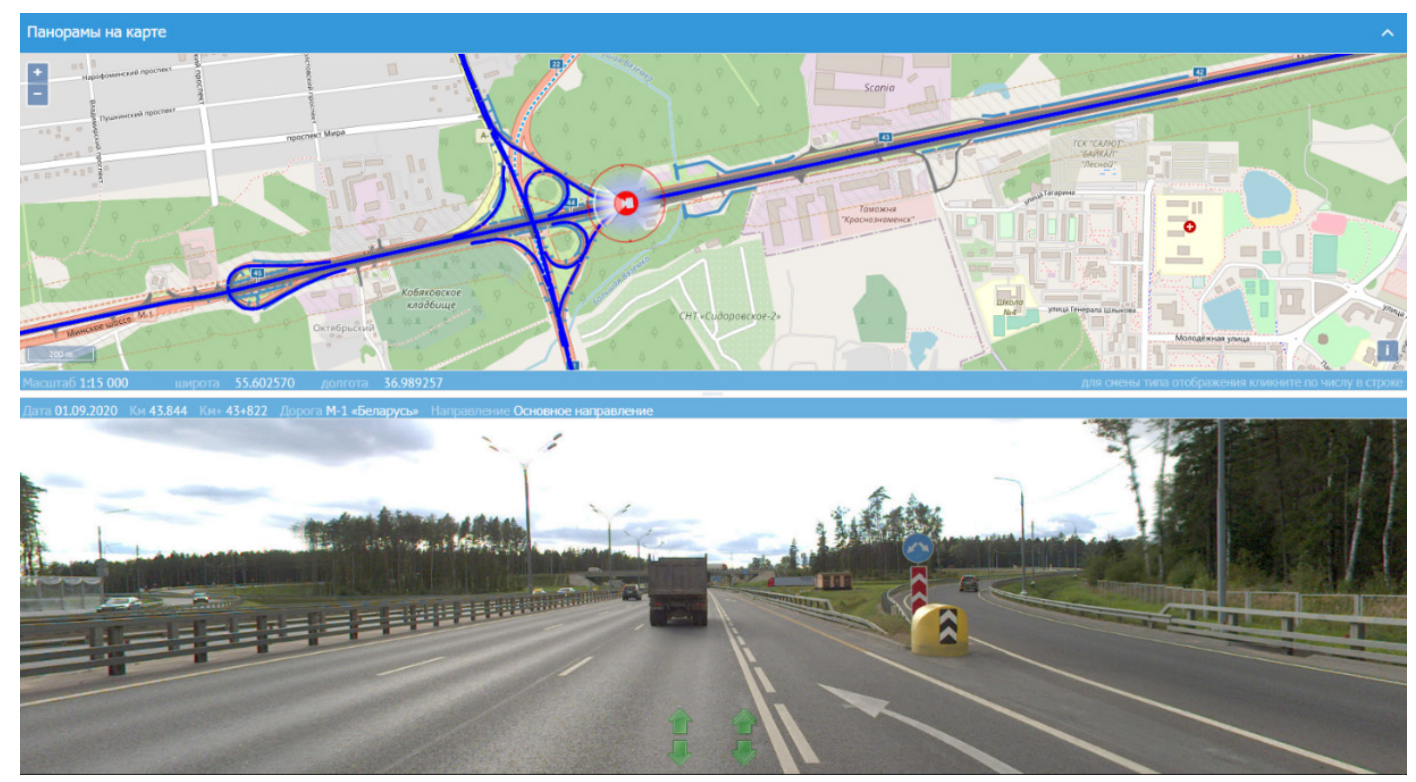

Figure 3. Screenshot of the navigation interface in photos with a 360-degree view 
redesign in individual areas due to insufficient level of detail shall be minimized. Based on the initially designed BIM model, through the integration of the financing and progress schedule, a CIM model to optimize construction and installation and, subsequently, an operational AIM model shall be created, supplemented with data on the estimated characteristics of structural elements and installed equipment's operation and wear.

As for the operation stage, information modeling solves the following tasks:

- planning of works and resources for road (road section) maintenance;

- planning of work and resources for works related to road operation, including road (road section) repairs and overhauls;

- planning of works and resources for road (road section) reconstruction;

- procurement of works and resources for road (road section) maintenance and operation;

- collection and accumulation of road (road section) diagnostics data as well as performance monitoring and management of the state of roads (road section) and their utilities;

- automated collection and processing of information from sensors and other systems installed along the road.

These works can also be performed using GIS technologies. The use of these BIM tools in the road industry will not only scale them up but also form a common approach to the structure and library of the digital road model's elements. This is evidence-based reasoning proving the fact that the road GIS reaches the highest level of maturity (in British classification) (BSI, 2007, 2013) - iBIM (Shamraeva et al., 2018) - and demonstrates BIM capabilities during practical application in road infrastructure. Russian specialists are currently developing competitive software solutions that will bring road management to a new environment of economic development.

The use of BIM tools in the implementation of transport infrastructure development projects will optimize time and save money when planning and introducing measures during the operation of facilities.

Interaction organization using a CDE at the stage of project implementation

For the FWKB project, specialists of Stroyproekt Institute developed a BIM model in the SINFO environment. According to Avtodor company, this model is suitable for breaking down construction and installation works into stages and getting a general idea of their progress. The company also determined to what extent it could be used for the operation and maintenance of infrastructure facilities (Dmitrienko et al., 2019). In the current state, the InfraBIM model can be used to get an idea of construction and installation works as well as structures under construction. A digital land plot model with an orthophoto could be another advantage.

However, its use without the development of S-INFO to break down construction and installation works into stages is quite difficult and even impossible. Usually, breaking down into stages implies the separation of the original objects. It is impossible to break the selected pavement structure down for a second time (Fig. 5). If the roadbed is to be constructed in two stages, it will be impossible to display only a part of the selected element. Using the model to break down construction and installation works into stages requires access to the original models of each element. Besides, temporary structures were not modeled. Therefore, we cannot control their influence on the boundaries of other structures. If it is required to accurately break down works into stages, we need to model temporary structures. A large amount of data (mainly design and construction data) shall be introduced into the object-related data model. Besides, earthwork structures (excavations and embankments) shall be modeled.

Upon completion of FWKB construction, it is planned to conduct acceptance diagnostics using unmanned aerial vehicles (UAVs) and mobile laboratories of the 5 th generation equipped with lidars and mobile laser scanning units (Evstigneev, 2019). In an integration laboratory, 3D models of roads in section view can be developed. Using a scanner, it is possible to collect data from a road section with a width of $7 \mathrm{~m}$ (at a speed up to $100 \mathrm{~km} / \mathrm{h}$ ), including from a depth of $7 \mathrm{~m}$ under the road pavement. The data obtained are processed automatically by special software and uploaded to the CDE. Concerned individuals and entities can use these data for the design, construction, maintenance, and repair of transport infrastructure facilities. Not only engineers and qualified operators but car enthusiasts as well can join the process of data registration. They will be able to take photos of any road pits and unevenness, violations in traffic sign installation, and, using a special app, send those to the shared database. It is expected that large arrays of information (hundreds of TB) will be accumulated.

Thus, the operational InfraBIM model of the FWKB will ensure uniform principles of data storage, access, and processing for the following applied tasks:

- certification and inventory of roads, artificial structures, and other assets;

- diagnostics of roads and artificial structures;

- collection of information on road traffic accidents;

- registration of traffic intensity and composition;

- evaluation of the level of road maintenance;

- technical registration of road works;

- surveys carried out for the development of traffic management projects;

- surveys and projects of road repairs, construction and reconstruction; 


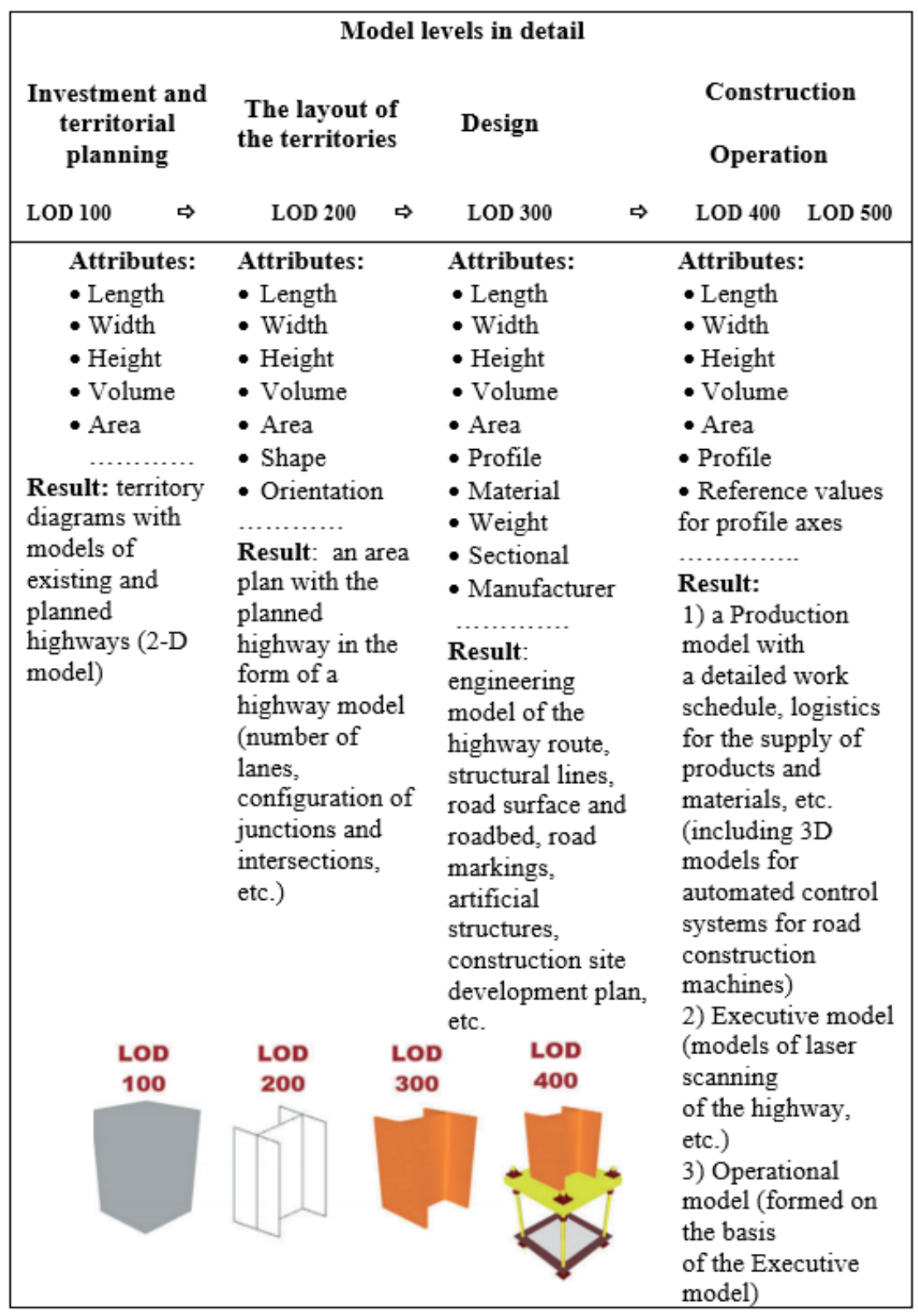

Figure 4. LOD in detail in project development

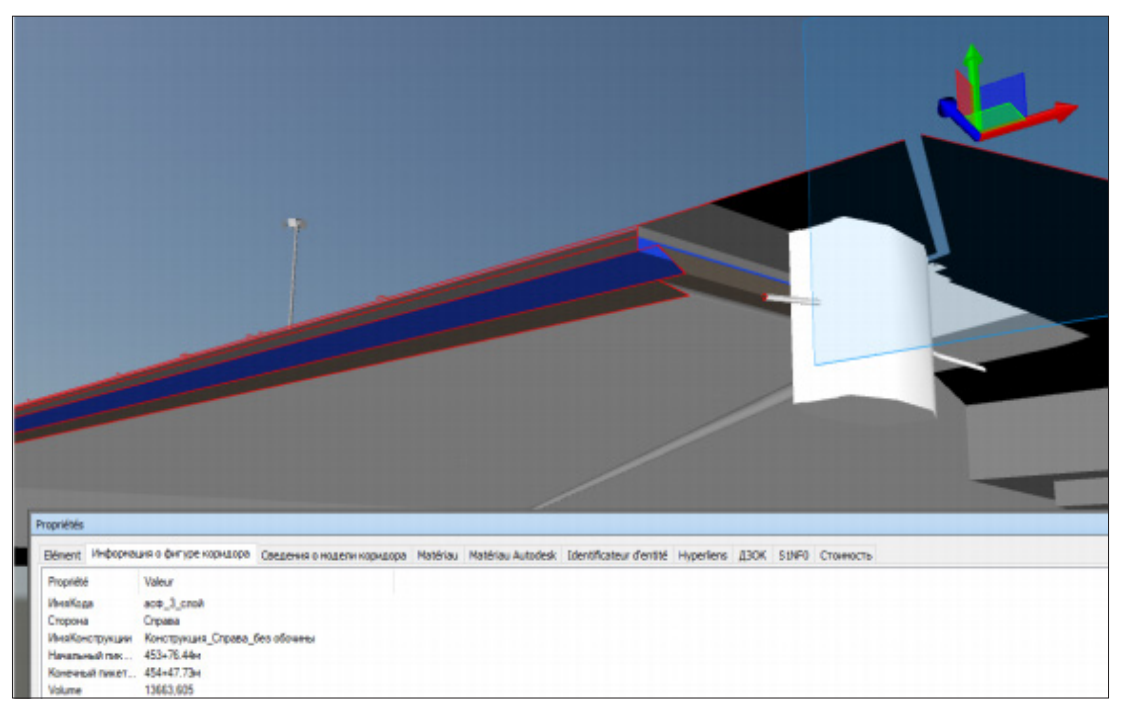

Figure 5. Pavement layer data 
- land and property registration.

In many cases, domestic software serves as a means of interaction between the state and business. The GIS of Avtodor company is an example of such interaction, which makes it possible to determine legally relevant data on transport infrastructure facilities and develop common standards and regulations for information exchange (Znobishchev and Shamraeva, 2019a). That is another benefit of BIM modeling when designing transport infrastructure facilities (Bryde et al., 2013).

The issues of using BIM tools in the implementation of transport infrastructure development projects are currently gaining more and more significance. They will help solve the main tasks in the road industry: optimize time and save money when planning and introducing measures at the stage of operation of infrastructure facilities.

The database shall be updated with the use of a special program. IndorRoad has the iFC data exchange format implemented for integrating data from BIM models. This function will be necessary in the future for infrastructure construction and reconstruction projects. To update plans and network diagrams, the ETL (Extract, Transform, Load) procedure can be used when connecting directly to the CDE without using IndorRoad. This issue should be addressed in order to limit human intervention in data entry.

\section{Conclusion}

The considered InfraBIM model of the FWKB was developed for the stages of design and design documentation development. For the purposes of road operation and maintenance, it shall be modified since the information model intended for use by the operating organization reflects the actual constructed facility. The original models need to be updated. New modeling is required in areas where significant changes were made in the project during construction and installation.

Thus, while there are no projects completely based on InfraBIM processes, the creation of a CDE is conducted in several parallel ways:

- a GIS ("operational BIM") is formed for the transport infrastructure in operation, which reflects the actual state of the facility and does not require significant costs for update and filling;

- starting from 2021, for all road construction projects, a BIM model is formed that covers the entire life cycle of the road.

However, domestic software solutions are currently suitable for the design stage only since the construction stage requires a decision of the public sector customer for the compulsory use of BIM and a CDE by all participants of the process (designer, contractor, and construction supervisor) with the choice of specific software solutions. Such developments are among the priority areas of information society development, as evidenced by Decree of the President of the Russian Federation No. 203, dated May 9, 2017, "On the Strategy for the Development of the Information Society in the Russian Federation for 2017-2030". Besides, they support national sovereignty over information flows in the transport sector of the Russian Federation. 


\section{References}

Abbasnejad, B. and Moud, H. I. (2013). BIM and basic challenges associated with its definitions, interpretations and expectations. International Journal of Engineering Research and Applications, Vol. 3, Issue 2, pp. 287-294.

Barannik, S. V. (2017). Review of the USA national BIM standard NBIMS-US V3. CAD \& GIS for Roads, No. 1 (8), pp. 4-8. DOI: 10.17273/CADGIS.2017.1.1.

Boykov, V. N., Kuzovlev, Ye. G. and Barannik, S. V. (2017). GIS of the automobile roads in the context of the paradigm of information modeling (BIM). Dorozhniki, No. 3 (11), pp. 66-69.

Bryde, D., Broquetas, M. and Volm, J. M. (2013). The project benefits of Building Information Modelling (BIM). International Journal of Project Management, Vol. 31, Issue 7, pp. 971-980. DOI: 10.1016/j.ijproman.2012.12.001.

BSI (2007). British Standard BS 1192:2007+A2:2016. Collaborative production of architectural, engineering and construction information. Code of practice. BSI, $40 \mathrm{p}$.

BSI (2013). PAS 1192-2:2013. Specification for information management for the capital/delivery phase of construction projects using building information modelling. BSI, $68 \mathrm{p}$.

Criminale, A., and Langar, S. (2017). Challenges with BIM implementation: a review of literature. 53rd ASC Annual International Conference Proceedings, Associated Schools of Construction. [online] Available at: https://www.researchgate.net/publication/317842173_Challenges_with_BIM_Implementation_A_Review_of_Literature [Date accessed January 11, 2021].

Dmitrienko, V. E., Kuzovlev, E. G. and Shamraev, L. G. (2019). GIS application of the Avtodor State Company for solving practical tasks of road maintenance. CAD \& GIS for Roads, No. 2 (13), pp. 52-59. DOI: 10.17273/CADGIS.2019.2.8.

Eastman, C., Teicholz, P., Sacks, R. and Liston, K. (2011). BIM Handbook: A guide to building information modeling for owners, managers, designers, engineers, and contractors. $2^{\text {nd }}$ Edition. Hoboken, NJ: John Wiley \& Sons, 624 p.

Evstigneev, I. A. (2019). Road infrastructure and highly automated vehicles. CAD \& GIS for Roads, No. 2 (13), pp. 44-50. DOI: $10.17273 / C A D G I S .2019 .2 .7$.

Gibadullin, A. A., Morkovkin, D. E., Hutarava, I. I., Stroev, P. V. and Pivovarova, O. V. (2020). Analysis and digital transformation of the transport sector of the Eurasian Economic Union. IOP Conference Series: Materials Science and Engineering, Vol. 918, 012231. DOI: 10.1088/1757-899X/918/1/012231.

Hardin, B. and McCool, D. (2015). BIM and construction management: proven tools, methods, and workflows. $2^{\text {nd }}$ edition. Indianapolis, IN: John Wiley \& Sons, $416 \mathrm{p}$.

Kazeev, I.M. (2020). Simulation modeling transport and technological complex. Educational Resources and Technologies, No. 1 (30), pp. 69-74. DOI: 10.21777/2500-2112-2020-1-69-74.

Linowes, J. and Babilinski, K. (2017). Augmented reality for developers: build practical augmented reality applications with Unity, ARCore, ARKit, and Vuforia. Birmingham: Packt Publishing, 548 p.

Shamraeva, V. (2020a). Analysis of business processes of construction and operation of highways on a toll basis using BIM tools. In: Information Technologies and Mathematical Modelling. ITMM 2020. Proceedings of the 19th International Conference named after A. F. Terpugov, December 2-5, 2020, Tomsk, Russia. Tomsk: Scientific Technology Publishing House, pp. 429-440.

Shamraeva, V. (2020b). Predicting the effectiveness of implementation of financial models for toll collection on the road. Transport Business of Russia, No. 1, pp. 37-41.

Shamraeva, V. V., Kuzovlev, E. G. and Barannik, S. V. (2018). Implementation of geographic information systems in the road sector as one of the directions of information modeling. Herald of Computer and Information Technologies, No. 6 (168), pp. 20-26. DOI: 10.14489/vkit.2018.06.pp.020-026.

Skvortsov, A. V. and Sarychev, D. S. (2015). Road project life cycle for information modeling. CAD \& GIS for Roads, No. 1 (4), pp. 4-14. DOI: 10.17273/CADGIS.2015.1.1.

Stumpf, A. L., Kim, H. and Jenicek, E. M. (2011). Early design energy analysis using Building Information Modeling technology. Arlington, VA: Office of the Assistant Chief of Staff for Installation Management, $90 \mathrm{p}$.

The American Institute of Architects (2013). E203-2013 Building Information Modeling and Digital Data Exhibit. [online] Available at: https://help.aiacontracts.org/public/wp-content/uploads/2020/12/AIA-E203-2013-Free-Sample-Preview. pdf [Date accessed 25.02.2021].

Znobishchev, S. V. and Shamraeva, V. V. (2019a). New approaches to construction of linear sections of the transport infrastructure with the use of BIM-modeling. BIM in Construction \& Architecture. Proceedings of the $2^{\text {nd }}$ International Conference, May 15-17, 2019. Saint Petersburg: Saint Petersburg State University of Architecture and Civil Engineering, pp. 124-129.

Znobishchev, S. and Shamraeva, V. (2019b). Practical use of BIM modeling for road infrastructure facilities. Architecture and Engineering, Vol. 4, No. 3, pp. 49-54. DOI: 10.23968/2500-0055-2019-4-3-49-54. 


\title{
INFRAВIM ДЛЯ УПРАВЛЕНИЯ БИЗНЕС-ПРОЦЕССАМИ СТРОИТЕЛЬСТВА И ЭКСПЛУАТАЦИИ АВТОМОБИЛЬНЫХ ДОРОГ
}

\author{
Виктория Викторовна Шамраева*, Евгений Анатольевич Савинов \\ Финансовый университет при правительстве Российской Федерации \\ Ленинградский проспект, 49, Москва, 125993, Россия \\ *E-mail: VVShamraeva@fa.ru
}

\begin{abstract}
Аннотация
Предметом исследования являются бизнес-процессы строительства и эксплуатации линейно протяженных участков автомобильных дорог. В статье рассмотрена геоинформационная система (ГИС) государственной компании «Автодор» (разработчик «ИндорСофт», Томск), и ее использование в целях эксплуатации и технического обслуживания объектов транспортной инфраструктуры на таких участках дорог. Объектом исследования является проект строительства Дальнего Западного обхода Краснодара (ДЗОК), являющийся частью транспортного коридора Север-Юг, и его реализация с помощью InfraВІМ-моделирования. Цель исследования: Описание структурированной базы данных ГИС государственной компании «Автодор» путем подключения различных инструментов InfraBIM для генерации и обновления информационной модели дороги. Методы: Предлагаемые программные решения для ГИС государственной компании «Автодор» при использовании InfraBIM-модели дорожной инфраструктуры: применение функционала ГИС на объекте; применение асинхронного редактирования и обработки данных без доступа к Интернету; обновление базы данных. Результаты: Разработка InfraBIM-моделей линейно - протяженных участков дорог при реализации проектов типа ДЗОК позволяет решать основные задачи содержания дороги - оптимизировать время и средства при планировании и реализации мероприятий на этапе эксплуатации объектов транспортной инфраструктуры.
\end{abstract}

\section{Ключевые слова}

ВІМ-моделирование, информационная модель дороги, геоинформационная система, транспортная инфраструктура, цифровая трансформация дорог, InfraBIM для строительства и обслуживания дорог. 